\title{
Security System Research in the Government Network
}

\author{
Y.Y. Ji \\ Communication Management Bureau of Zhejiang \\ Hangzhou, Zhejiang, China
}

\author{
C.L. Yu \\ HangZhou Dianzi University \\ Hangzhou, Zhejiang, China
}

\author{
B. Wang \\ Confidential Bureau of Yuhe \\ Lishui, Zhejiang, China
}

\begin{abstract}
Government network security issues have become increasingly prominent. In this paper, after analyzing the existing government network security system of Yunhe county government network, we pointed out that the threats to the status quo of the government network security. And then we proposed specific rehabilitation programs for the deficiencies of the original network.
\end{abstract}

Keywords-government network; network security system; network reform

\section{INTRODUCTION}

As a special application area of information network, government network demands very high security level for data and information operating in it [1]. It will surely cause serious losses if government network system were hacked. As a consequence, it is very necessary to improve the structure of the security system and enhance the performance of the security system, which is very significant to improve the safety of government network.

\section{RELEVANT RESEARCH}

\section{A. Internet Security Protection System}

Internet security protection system is consist of security operating system, application system, firewall, internet monitoring, security scanning, communication encryption, internet anti-virus, etc. each module is able to cover part of the system function [2].

\section{B. Analysis for Previous Government Network Safety}

Take the government network of Yunhe county in Lishui as an example, there are some safety risks in the previous government network.

a. VPN safety risks. As a main way to access government external network from internet, however there is no safety equipment behind the VPN equipment and this makes users, who login government external network via VPN, lack of network protection and safety supervision [3].

b. Server isolation. Server shares the same network with ordinary users without safety separation and access control policy. It would be dangerous if hacking comes from internal network. c. Different switchers in the backbone network. As the construction of backbone network was not done at one time, there are many different switcher brands and models, which may cause port mismatch.

The previous network topology in Yunhe county is shown as figure1 below,

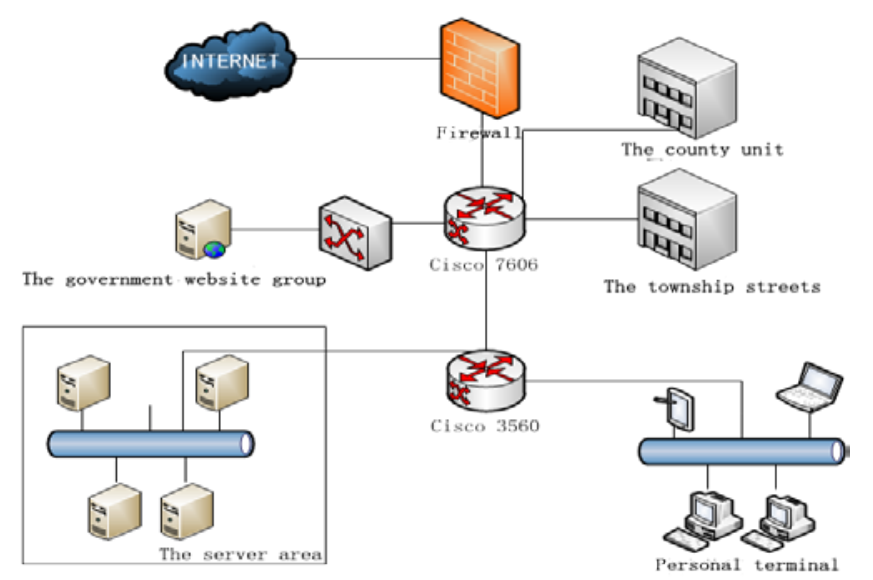

FIGURE I. PREVIOUS NETWORK TOPOLOGY IN YUNHE COUNTY.

\section{REFORM PROJECT OF GOVERNMENT NETWORK SAFETY STRUCTURE}

\section{A. Firewall}

Deploy the firewall between the core switcher in internal network and internet. Considering the necessity of safety redundancy and high performance of network, the firewall shall work at a dual-A status to form redundant double-link structure [4]. Figure 2 shows the reformed firewall deployment plan. 


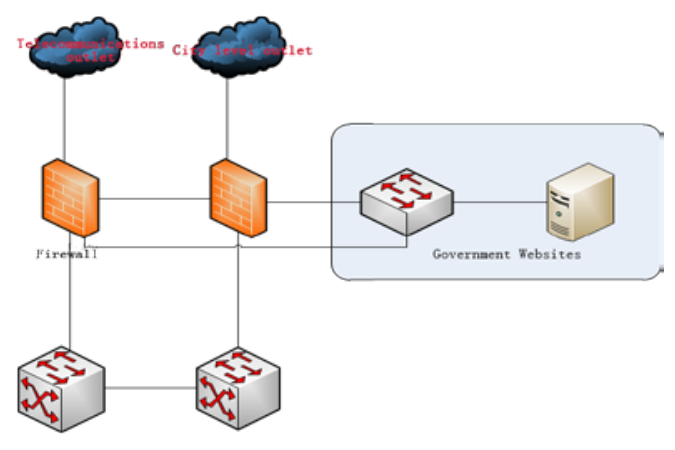

FIGURE II. FIREWALL DEPLOYMENT PLAN.

\section{B. $V P N$}

Government network demands safe transmission when important business data transforming on the internet, and the basic requirements are as follows,

ensure the truth and integrity of data, and the confidentiality of channel. Offer dynamic key exchange, united safety management service, security protection and access control, etc. In order to reduce the impact on present application system and make sure there is no impact on development of some new business applications, VPN network shall be deployed to offer convenience to access internal network via VPN for government workers who are on a business trip ${ }^{[5]}$.

The VPN deployment plan is shown in figure 3.

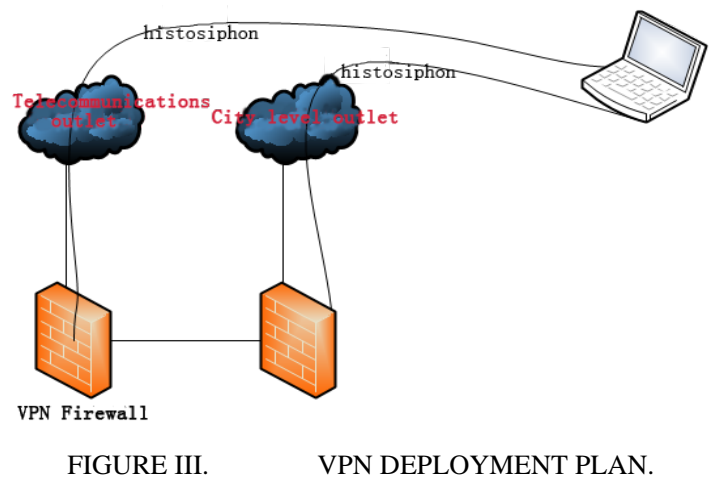

\section{IDS (Intrusion Detection System)}

IDS should be deployed on the boundary of government network and information system to detect Trojans and vulnerabilities from external network ${ }^{[6]}$ [7]. The IDS is shown in figure 4.

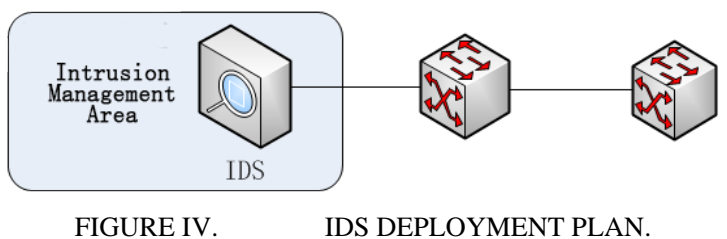

This IDS can detect any activity which passes this segment and monitor the dynamic network in real time. It will find intrusion via characteristics of packets, therefore fend against network attack from internal and external environment. In order to improve the intrusion detection capability of the system, continuous update of intrusion characteristics with system version upgrade is necessary.

This IDS applies by-path structure, all data go through the switcher are transmit to IDS via a mirror port on the core switcher. After analyzing the received data, the IDS will give an alarm or call the firewall when finding an attack to stop it.

\section{REFORMED GOVERNMENT NETWORK}

This reformation plan divided the government network and information system into separated safety area. Business system area, which is a key protected object, was set up as the core of government network and information system in Yunhe county. So far most safety risks come from the internal internet, an ordinary PC terminal can access servers arbitrarily. Besides, their authority is too high for general PC terminal users, therefore, mishandling, virus infection and malicious attacks may bring high safety risks to servers. So the server area is separated by firewall to realize security isolation between PC terminals area and business area. Reformed government network topology is shown in figure 5 .

After the implementation of access control and security isolation between the network in Yunhe county and the Internet, which realized by the firewall between those 2 networks, corresponding intrusion protection and activity management are applied in deep data attack analysis. When attack happens it will directly clean it up or make a warning, which improves the safety of government network system in Yunhe county.

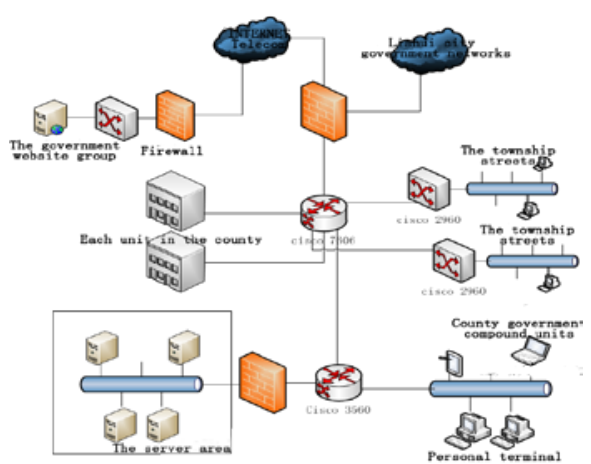

FIGURE V. REFORMED GOVERNMENT NETWORK TOPOLOGY.

\section{DATA COMPARISON ANALYSIS BEFORE AND AFTER NETWORK REFORMATION}

Because of the specificity of network security devices, it is difficult to define key data when taking test on data. Therefore we can only extract monitoring results on the network repeatedly to test whether the safety data function well. This article take 7 representative and meaningful nodes as test site to measure average delay and packet loss rate during the visit from Yunhe county to each test site. Test data can be reference when comparing and analyzing network situations before and after reformation.

\section{A. Data before Network Reformation}

Average delay and packet loss rate before network reformation is shown as table 1 and table 2 . 


\section{B. Data after Network Reformation}

Average delay and packet loss rate after network reformation is shown as table 3 and table 4 .

\section{Analysis}

As the test results shown, it is obvious that government networks have a lower risk of attacking from professional hacker. As network congestion caused by virus is more common, it is very important for network manager to find reasons for congestion and resource of virus.

\section{CONCLUSION}

With the widespread use of government network in government work, security of government network is more and more significant. This article chooses government network of Yunhe county in Lishui city as example, and raises specific network security reforming plan on the base of previous security detection system of government network. After the analysis of test data before and after network reformation, we can draw a conclusion that the probability the government network surfer attacks from professional hacker is reduced obviously. Hence it is significantly meaningful for government network security improvement.

\section{REFERENCES}

[1] Feng Ma, Ying-li Zhang, Yu-feng Yang, Commonly security technologies used in E-government network. Industrial Engineering, 7(2), 2004.

[2] Ai-ming Chen, Computer security and confidentiality. Electronic Industry publication, 2004.

[3] Yu-guo Wang, Security technology for computer information systems. Information Systems Engineering, 11, 2013.

[4] Jing-long Cai, Qian Qin, Key technology of firewall research. Science \& Technology Information, 27, 2008.

[5] Na Xu, Chao Zhang, Discussion for computer LAN security measures. China Science \& Technology Panorama Magazine, 10, 2013.

[6] Jian-chun Jiang, Heng-tai Ma, Dang-en Ren, A Survey of Intrusion Detection Research on Network Security. Journal of Software, 11(11), 2000

[7] Xiao-jing He, Research for network security intrusion detection technology. Public Communication of Science \& Technology, 2, 2012.

TABLE I. AVERAGE DELAY BEFORE NETWORK REFORMATION (MS).

\begin{tabular}{|l|c|c|c|c|c|c|c|}
\hline & $\begin{array}{l}\text { To City Information } \\
\text { Center HUAWEI } \\
8512\end{array}$ & $\begin{array}{l}\text { To City Information } \\
\text { Center East } \\
\text { Computer Room } \\
\text { cisco7609 }\end{array}$ & $\begin{array}{l}\text { Tounty cisco7606 } \\
\text { Coung }\end{array}$ & $\begin{array}{l}\text { To Yunhe } \\
\text { County cicso } \\
7606\end{array}$ & $\begin{array}{l}\text { To Lishui City } \\
\text { DNS }\end{array}$ & $\begin{array}{l}\text { To Yunhe } \\
\text { County DNS }\end{array}$ & $\begin{array}{l}\text { To Normal } \\
\text { PC }\end{array}$ \\
\hline The 1st Time & 2123 & 2144 & 3001 & 1454 & 1355 & 1122 & 1011 \\
\hline The 2nd Time & 13 & 12 & 15 & 2 & 3 & 1 & 11 \\
\hline The 3rd time & time out & time out & time out & time out & time out & time out & time out \\
\hline The 4th time & 13 & 12 & 15 & 2 & time out & 1 & 11 \\
\hline The 5th time & 1823 & 1944 & 2801 & 1447 & 1055 & 922 & 911 \\
\hline
\end{tabular}

TABLE II. PACKET LOSS RATE BEFORE NETWORK REFORMATION (\%).

\begin{tabular}{|l|c|c|c|c|c|c|c|}
\hline & $\begin{array}{l}\text { To City Information To City Information } \\
\text { Center HUAWEI } \\
\text { 8512 }\end{array}$ & $\begin{array}{l}\text { To Songyang } \\
\text { Counter East Computer } \\
\text { Room cisco7609 }\end{array}$ & $\begin{array}{l}\text { To Yunhe } \\
\text { County cicso } \\
7606\end{array}$ & $\begin{array}{l}\text { To Lishui } \\
\text { City DNS }\end{array}$ & $\begin{array}{l}\text { To Yunhe } \\
\text { County } \\
\text { DNS }\end{array}$ & $\begin{array}{l}\text { To Normal PC } \\
\text { The }\end{array}$ \\
\hline The 1st Time & 48 & 47 & 65 & 42 & 40 & 34 & 29 \\
\hline The 2nd Time & 0.7 & 0.7 & 0.8 & 0.1 & 0.2 & 0.0 & 0.0 \\
\hline The 3rd time & 100 & 100 & 100 & 100 & 100 & 100 & 100 \\
\hline The 4th time & 0.7 & 0.7 & 0.8 & 0.1 & 100 & 0.0 & 0.0 \\
\hline The 5th time & 40 & 39 & 50 & 37 & 30 & 24 & 18 \\
\hline
\end{tabular}

TABLE III. AVERAGE DELAY AFTER NETWORK REFORMATION (MS).

\begin{tabular}{|l|c|c|l|c|c|c|c|}
\hline & $\begin{array}{l}\text { To City Information } \\
\text { Center HUAWEI } \\
8512\end{array}$ & $\begin{array}{l}\text { To City Information } \\
\text { Center East Computer } \\
\text { Room cisco7609 }\end{array}$ & $\begin{array}{l}\text { To Songyang } \\
\text { County } \\
\text { cisco7606 }\end{array}$ & $\begin{array}{l}\text { To Yunhe } \\
\text { County } \\
\text { cicso7606 }\end{array}$ & $\begin{array}{l}\text { To Lishui City } \\
\text { DNS }\end{array}$ & $\begin{array}{l}\text { To Yunhe } \\
\text { County DNS }\end{array}$ & To Normal PC \\
\hline The 1st Time & 12 & 9 & 15 & 2 & 3 & 1 & 11 \\
\hline The 2nd Time & 13 & 12 & 15 & 1 & 3 & 1 & 11 \\
\hline The 3rd time & 13 & 12 & 15 & 2 & 3 & 1 & 11 \\
\hline The 4th time & 14 & 13 & 15 & 2 & 3 & 1 & 10 \\
\hline The 5th time & 13 & 12 & 15 & 2 & 3 & 2 & 1750 \\
\hline
\end{tabular}

TABLE IV. PACKET LOSS RATE AFTER NETWORK REFORMATION (\%).

\begin{tabular}{|l|c|c|c|c|c|c|c|}
\hline & $\begin{array}{l}\text { To City Information } \\
\text { Center HUA WEI } \\
8512\end{array}$ & $\begin{array}{l}\text { To City Information } \\
\text { Center East Computer } \\
\text { Room cisco7609 }\end{array}$ & $\begin{array}{l}\text { To Songyang } \\
\text { County cisco7606 }\end{array}$ & $\begin{array}{l}\text { To Yunhe County } \\
\text { cicso7606 }\end{array}$ & $\begin{array}{l}\text { To Lishui } \\
\text { City DNS }\end{array}$ & $\begin{array}{l}\text { To Yunhe } \\
\text { County DNS }\end{array}$ & \begin{tabular}{l} 
To Normal PC \\
\hline The 1st Time
\end{tabular} \\
\hline The 2nd Time & 0.6 & 0.7 & 0.8 & 0.1 & 0.2 & 0.0 & 0.0 \\
\hline The 3rd time & 0.7 & 0.8 & 0.8 & 0.1 & 0.2 & 0.0 & 0.0 \\
\hline The 4th time & 0.7 & 0.7 & 0.8 & 0.1 & 0.2 & 0.0 & 0.0 \\
\hline The 5th time & 0.6 & 0.7 & 0.7 & 0.0 & 0.2 & 0.0 & 0.0 \\
\hline
\end{tabular}

